\title{
PERTANGGUNGJAWABAN HUKUM BADAN PENYELENGGARA JAMINAN SOSIAL (BPJS) DITINJAU DARI UNSUR KUALITAS PELAYANAN KESEHATAN PADA PASIEN PESERTA JAMINAN KESEHATAN NASIONAL $(\mathrm{JKN})$
}

\author{
${ }^{1}$ Muniroh Hanafiah, ${ }^{2}$ Dey Ravena ${ }^{3}$ Chepi A. Firman \\ 1,2 3 Magister Ilmu Hukum, Pascasarjana Universitas Islam Bandung, \\ email: ${ }^{1}$ poyhan1989@gmail.com,
}

\begin{abstract}
Abstrak. Berdasarkan Pasal 20 ayat (1) Undang-Undang Kesehatan No. 36 Tahun 2009 Tentang Kesehatan, pemerintah bertanggung jawab atas pelaksanaan jaminan kesehatan masyarakat melalui sistem jaminan sosial nasional bagi upaya kesehatan perorangan. Untuk dapat memenuhi kewajibannya Pemerintah Indonesia menyeleggarakan jaminan sosial di bidang kesehatan. Pada tahun 2004 dikeluarkan Undang-Undang Nomor 40 Tahun 2004 Tentang Sistem Jaminan Sosial Nasional (SJSN). Program Jaminan Kesehatan Nasional yang diselenggarakan oleh BPJS Kesehatan, implementasinya telah sejak dimulai sejak 1 Januari 2014. Salah satu permasalahan yang timbul dengan menjalankan program Jaminan Kesehatan Nasional adalah permasalahan pertanggungjawaban hukum BPJS atas buruknya pengelolaan program kualitas layanan kesehatan yang diimplementasikan pada rumah sakit menjadi suatu hal yang terpisah dengan teori pertanggungjawaban hukum. Tujuan dari penilitian ini adalah untuk menentukan apakah BPJS dapat mempertanggungjawabkan secara hukum atas buruknya kualitas pelayanan kesehatan yang diselenggarakan oleh rumah sakit kepada pasien. Dalam penelitian ini metode pendekatan yang digunakan adalah yuridis normatif, dengan menggunakan data sekunder yang terdiri dari bahan hukum primer, sekunder dan tersier yang diperoleh dari studi kepustakaan yang kemudian dianalisis menggunakan metode yuridis kualitatif. Hasil penelitian ini menunjukan bahwa bentuk dan aspek pertanggungjawaban Hukum BPJS digunakan teori Rechtmatigheid dan Doelmatigheid, unsur perbuatan melawan hukum BPJS bisa ditentukan oleh Pengukuran dan evaluasi kualitas pelayanan kesehatan BPJS dengan menggunakan indicator perjanjian kredensialing dan unsure kerugian yang diderita Rumah sakit dan pasien yang dilakukan oleh audit BPK, akuntan publik dan BPKP agar unsur perbuatan melawan hukum dapat di buktikan, tidak hanya pertanggungjawaban segi akuntabilitas GCG saja, namun BPJS sebagai badan hukum harus dipersamakan dengan hukum.
\end{abstract}

\section{Kata Kunci: Badan Penyelenggara Jaminan Sosial (BPJS), Kesehatan, Pertanggungjawaban Hukum, Kualitas Pelayanan Kesehatan}

\begin{abstract}
According to Article 20 paragraph 1 of the Healthcare Law No. 36 of 2009, the government is responsible for the social welfare of its people, which includes the healthcare system. In order to achieve this, the Indonesian Government implemented the Social Healthcare program that started in $1^{\text {st }}$ January 2014. One of the challenges face in implementing the Social Healthcare program is the legal accountability of the Indonesian Body of the social healthcare service which is commonly known as BPJS Kesehatan for the poor quality of healthcare in the hospital that is given to patients. This research is done with the intention of finding out whether or not BPJS Kesehatan can be legally hold responsible for the quality of the healthcare given to patient. Based The method used in this research is juridicial normative. According to the result of this study, the elements of unlawful act commited by BPJS Kesehatan can be determined by using the credentialing agreement form between BPJS Kesehatan and the hospital as an indicator. The evaluation to determine whether or not BPJS Kesehatan has committed unlawful act against the hospital (that is working together with it) and patients can be done by BPK, Public accountants and BPKP.
\end{abstract}


Keywords: Badan Penyelenggara Jaminan Sosial (BPJS), Health, Legal Responsibility, Quality of Health Services

\section{A. PENDAHULUAN}

Sistem jaminan sosial nasional merupakan program negara yang bertujuan memberikan kepastian perlindungan dan kesejaheraan sosial bagi seluruh rakyat. Untuk mewujudkan tujuan sistem jaminan sosial nasional perlu dibentuk badan penyelenggara yang berbentuk badan hukum berdasarkan prinsip kegotongroyongan, nirlaba, keterbukaan, kehati-hatian, akuntabilitas, portabilitas, kepersertaan bersifat wajib, dana amanat dan hasil pengelolaan dana jaminan sosial seluruhnya untuk pengembangan program dan untuk sebesar-besar kepentingan perserta.

Kesadaran tentang pentingnya jaminan perlindungan sosial terus berkembang sesuai amanat pada perubahan UUD 1945 Pasal 134 ayat 2, yang menyebutkan bahwa negara mengembangkan Sistem Jaminan Sosial bagi seluruh rakyat Indonesia. Dengan dimasukkannya Sistem Jaminan Sosial ke dalam perubahan UUD 1945, kemudian terbitnya Undang-Undang Nomor 40 Tahun 2004 tentang Sistem Jaminan Sosial Nasional (SJSN) menjadi suatu bukti yang kuat bahwa pemerintah dan pemangku kepentingan terkait memiliki komitmen yang besar untuk mewujudkan kesejahteraan sosial bagi seluruh rakyatnya.

Untuk dapat memenuhi kewajibannya Pemerintah Indonesia menyelenggarakan beberapa bentuk jaminan sosial di bidang kesehatan DOI: https://doi.org/10.29313/aktualita.v2i1.4679 diantaranya adalah melalui PT Askes (Persero) dan PT Jamsostek (Persero) yang melayani antara lain pegawai negeri sipil, penerima pensiun, veteran, dan pegawai swasta. Untuk masyarakat miskin dan tidak mampu, pemerintah memberikan jaminan melalui skema Jaminan Kesehatan Masyarakat (Jamkesmas) dan Jaminan Kesehatan Daerah (Jamkesda).

Namun demikian, skema-skema tersebut masih terfragmentasi, terbagibagi sehingga biaya Kesehatan dan mutu pelayanan menjadi sulit terkendali. Untuk mengatasi hal tersebut, pada tahun 2004 dikeluarkan Undang-Undang Nomor 40 Tahun 2004 tentang Sistem Jaminan Sosial Nasional (SJSN). Undang-Undang Nomor 40 Tahun 2004 ini mengamanatkan bahwa program jaminan sosial wajib bagi seluruh penduduk termasuk program Jaminan Kesehatan melalui suatu badan penyelenggara jaminan sosial. Badan penyelenggara jaminan sosial telah diatur dengan Undang-Undang Nomor 24 Tahun 2011 tentang Badan Penyelenggara Jaminan Sosial (BPJS) yang terdiri dari BPJS Kesehatan dan BPJS Ketenagakerjaan.

Untuk program jaminan kesehatan yang diselenggarakan oleh BPJS Kesehatan, implementasinya telah dimulai sejak 1 Januari 2014. Jumlah peserta program Jaminan Kesehatan Nasional yang tercantum hingga Januari 2017 terdapat 175 juta peserta. Selanjutnya program jaminan kesehatan 
tersebut disebut sebagai program Jaminan Kesehatan Nasional (JKN). Pengaturan teknis pelaksanaan lebih lanjut program JKN dituangkan dalam berbagai peraturan sebagai turunan dari kedua Undang-Undang tersebut diatas, baik dalam bentuk Peraturan Pemerintah (PP), Peraturan Presiden (Perpres), Peraturan Menteri Kesehatan (Permenkes), Keputusan Menteri Kesehatan (Kepmenkes), Surat Edaran (SE) Menteri Kesehatan, Pedoman Pelaksanaan (Manlak), Petunjuk Teknis (Juknis), Panduan Praktis dan lain-lain. BPJS Kesehatan menyelenggarakan pelayanan kesehatan yang mencakup pelayanan promotif, preventif, kuratif, dan rehabilitatif termasuk pelayanan obat dan bahan medis sesuai dengan kebutuhan medis yang diperlukan. Pelayanan kesehatan yang dijamin oleh BPJS Kesehatan meliputi semua fasilitas kesehatan dari fasilitas kesehatan tingkat pertama dan fasilitas kesehatan tingkat lanjutan termasuk fasilitas kesehatan penunjang seperti laboratorium, instalasi farmasi Rumah sakit, apotek dan lainnya.

Rumah sakit adalah salah satu dari penyelenggaraan pelayanan kesehatan atau lebih tepat disebut sebagai sarana kesehatan. Salah satu dari kewajiban rumah sakit adalah merawat pasien sebaik-baiknya sesuai dengan standar operation procedure serta menjaga mutu perawatan dan pelayanan kesehatan. Di Indonesia rumah sakit yang sudah tergabung dalam Perhimpunan Rumah Sakit Seluruh Indonesia (PERSI) telah menetapkan Kode Etik Rumah Sakit Indonesia yang memuat rangkuman nilainilai dan norma-norma perumahsakitan sebagai pedoman bagi pihak yang terlibat dan berkepentingan dalam penyelenggaraan dan pengelolaan perumahsakitan di Indonesia. Pelayanan rumah sakit juga diatur di dalam kode etik rumah sakit, dimana kewajiban rumah sakit terhadap karyawan, pasien dan masyarakat diatur. Dampak lingkungan yang ditimbulkan harus diatur dengan baik hingga tidak merugikan masyarakat, namun sayangnya meski perjanjian kredensialing rumah sakit dan BPJS telah ditetapkan, terdapat rumah sakit yang mengalami kesulitan dalam menerapkan kualitas pelayanan kesehatan, dikarenakan proses reclaim rumah sakit pada BPJS terkendala administrasi dan waktu, maka hal ini berdampak pada banyak pasien yang tidak mendapatkan pelayanan kesehatan yang dibutuhkan pada waktu yang tepat. Hal ini bisa berakibat fatal hingga kematian.

Berdasarkan latar belakang yang telah diuraikan, permasalahan yang ada dapat dirumuskan sebagai berikut:

1. Apakah BPJS dapat mempertanggungjawabkan secara hukum dari ditinjau dari unsur kualitas pelayanan kesehatan pasien peserta Jaminan Kesehatan Masyarakat menurut Undang-Undang No. 24 Tahun 2011 Tentang Badan Pelayanan Jaminan Sosial (BPJS)?

2. Bagaimanakah Bentuk Pertanggungjawaban hukum BPJS ditinjau dari unsur kualitas pelayanan kesehatan pasien peserta Jaminan Kesehatan Masyarakat 
Muniroh Hanafiah, Dey Ravena, Chepi A. Firman, Pertanggungjawaban Hukum Badan Penyelenggara...

berdasarkan Undang-Undang

No. 24 Tahun 2011 Tentang

Badan Pelayanan Jaminan Sosial (BPJS)?

Tujuan dari melakukan penelitian ini adalah sebagai berikut:

1. Menemukan dan menganalisa bentuk pertanggungjawaban hukum BPJS ditinjau dari unsur kualitas pelayanan kesehatan terhadap pasien peserta Jaminan Kesehatan Masyarakat menurut Undang-Undang No. 24 Tahun 2011 Tentang Badan Pelayanan Jaminan Sosial (BPJS).

2. Menemukan dan menganalisa proses Pertanggungjawaban hukum BPJS pertanggungjawaban hukum BPJS ditinjau dari unsur kualitas pelayanan kesehatan pasien peserta Jaminan Kesehatan Masyarakat berdasarkan Undang-Undang No. 24 Tahun 2011 Tentang Badan Pelayanan Jaminan Sosial (BPJS).

Dari penelitian ini diharapkan dapat memberikan manfaat secara teoritis dan juga secara praktis. Secara teoritis diharapkan penelitian dapat sebagai bahan masukan bagi badan hukum BPJS mengenai bentuk pertanggungjawaban laporan pengelolaan dan keuangan sangat menentukan kualitas pelayanan kesehatan bagi pasien peserta BPJS di rumah sakit dan sebagai bahan masukan bagi Badan Penyelenggara Jaminan Sosial terhadap bentuk pertanggungjawaban hukum BPJS ditinjau dari kualitas pelayanan BPJS. Secara praktis diharapkan penelitian ini dapat dapat membentuk pembangunan bangsa dan Negara supaya pemerintah DOI: https://doi.org/10.29313/aktualita.v2i1.4679 dapat meningkatkan kualitas pelayanan kesehatan untuk Peserta BPJS Kesehatan agar mereka dapat mendapatkan pelayanan kesehatan sesuai dengan kebutuhan mereka dan untuk penulis sendiri untuk menjadi wahana untuk menggembangakan pola pikir dan penalaran serta menerapkan ilmu yang sudah didapati.

Penelitian ini menggunakan pendekatan yuridis normatif dengan spesifikasi deskriptif analitis yaitu penelitian yang menggambarkan dan menganalisa masalah yang ada dan termasuk dalam jenis penelitian kepustakaan (library research) yang akan disajikan secara deskriptif.

\section{B. PEMBAHASAN}

B.1. Pengertian Pertanggungjawaban

Secara leksikal Pertanggungjawaban berasal dari kata tanggungjawab yang berarti keadaan wajib menanggung segala sesuatu berupa penuntunan diperkarakan dan dipersalahkan sebagai akibat dari sikap sendiri atau pihak lain. Selain itu Tanggungjawab merupakan kata benda yang dapat dipahami melalui sikap, tindakan, dan perilaku. Istilah pengertian pertanggungjawaban yang telah dibahas mengacu pada pertanggungjawaban seseorang dapat dituntut, diperkarakan, dan dipersalahkan dan menerima beban sebagai akibat sendiri atau akibat perbuatan orang lain, dan menimbulkan kerugian pada orang lain.

Berdasarkan Harun Al-Rasyid Pertanggungjawaban dapat dibagi kedalam dua pengertian yaitu:

1. Pertanggungjawaban dalam arti sempit, yaitu pertanggungjawaban tanpa sanksi.

2. Pertanggungjawaban arti luas, yaitu pertanggungjawaban yang 
disertai oleh sanksi.

Pinto, sebagaimana dikutip oleh Firdaus (2007:69), membedakan responsibility dan liability sebagai berikut:

1. Responsibility ditunjukan akan adanya suatu indikator tertentu yang terlebih dahulu ditentukan sebagai suatu kewajiban, yang harus ditaati yang menyebabkan lahirnya suatu tanggungjawab.

2. Liability cenderung merujuk pada suatu akibat yang timbul darir sebab kegagalan untuk memenuhi standar tertentu yang telah ditetapkan. Bentuk tanggungjawab diwujudkan dalam suatu bentuk ganti rugi dan pemulihan terhadap segala kerugian.

Kamus hukum karya Hendry Campbel Black (1979:823) menggunakan kata Liability dan Responsibility secara berbeda, liability is a broad legal term (Istilah hukum yang luas), dimana didalamnya mengandung makna yang paling komprehensif, meliputi hampir setiap karakter resiko atau pertanggungjawaban yang pasti, yang bergantung atau yang mungkin: hal itu dapat didefinisikan untuk memahami; semua karakter hak dan kewajiban.

Responsibility diartikan sebagai "The obligation to answer for an act done, and to repair an otherwise make restitution for any injury it may have cause"

Menururt pengertian in kewajiban menjawab atas pelaksanaan undang-undang dan memperbaiki atau dengan kata membuat ganti rugi atas suatu kerusakan yang mungkin telah dilakukan dan menggunakan terminologi liabiliti sebagai pertanggungjawaban hukum dapat diartikan sebagai tanggung gugat atas suatu kesalahan yang dilakukan oleh subjek hukum. Sedangkan Responsibility dimaknai sebagai pertanggungjawaban politik..

\section{Tanggungjawab}

(Verantwoordelijke) (Arifin Soeria Atmadja, 1986:250) adalah kewajiban untuk memikul pertanggungjawabandan hingga memikul kerugian bila dituntut baik dalam kaitan dengan hukum maupun dalam Administrasi. Menurut Prof.Arifin, Pertanggungjawaban merupakan kebebasan bertindak untuk melaksanakan tugas yang dibebankan tetapi pada akhirnya tidak bisa melepaskan diri dari resultante kebebasan bertindak, berupa penuntutan untuk melaksanakan secara layak apa yang diwajibkan kepadanya, pandangan tersebut bersesuaian dengan ensiklopedia Administrasi yang mendefinisikan responsibility adalah keharusan seseorang untuk melaksanakan secara layak apa yang dikewajiban kepadanya(Sutarto, 2003:29).

Accountability berdasarkan Webster Dictionary (1983:15) dapat dikonstrusikan sebagai the state of being accountable, responsible or liable, beberapa unsur yang memenuhi pengertian accountable adalah sebagai berikut:

1. Bertanggungjawab dapat disebut memberi laporan; yang dapat dipertanggungjawab kepada Tuhannya untuk semua perilakunya.

2. Mampu memberi keterangan yang memuaskan secara keluar,

3. Suatu yang mungkin dihitung atau untuk dihitung.

Kewenangan delegasi adalah kewenangan yang diperoleh dari pelimpahan satu organ pemerintah kepada organ lain dengan dasar peraturan 
perundangan. Dalam skema delegasi tanggungjawab atas kebijakan yang dijalankan turut beralih kepada yang mendapat delegasi (Sutarto, 2003:18).

\section{B.2. Pelayanan Kesehatan}

Pelayanan kesehatan merupakan suatu kumpulan dari berbagai jenis layanan kesehatan, berawal dari promosi kesehatan, pencegahan penyakit, penyembuhan penyakti rehaibilitasi hingga transplantasi organ (Buchbinder, Shanks, 2014:124). Pelayanan kesehatan dapat diselenggarakan sendiri atau secara bersama-sama dalam suatu organisasi untuk memelihara dan meningkakan kesehatan, mencegah dan menyembuhkan penyakit serta memulihkan kesehatan perseorangan, keluarga, kelompok dan ataupun masyarakat (Komalawti, 2002:78).

Menurut Undang-Undang No. 36 Tahun 2009 tidak ditemukan rumusan pengertian mengenai pelayanan kesehatan, namun hanya ada rumusan mengenai upaya kesehatan di dalam Ketentuan Umum Pasal 1 ayat 11 yang menyatakan bahwa:

"Upaya kesehatan adalah setiap kegiatan dan/atau serangkaian kegiatan yang dilakukan secara terpadu, terintegrasi dan berkesinambungan untuk memelihara dan meningkatkan derajat kesehatan masyarakat dalam bentuk pencegahan penyakit, peningkatan kesehatan, pengobatan penyakit, dan pemulihan kesehatan oleh pemerintah dan/atau masyarakat."

Secara garis besar pelayanan kesehatan dapat dibedakan atas dua bentuk dan jenis yaitu, Pelayanan kedokteran dan Pelayanan kesehatan masyarakat. Pelayanan kesehatan masyarakat merupakan pelayakan kesehatan yang memiliki tujuan utama untuk memelihara dan meningkatkan kesehatan serta mencegah penyakit dan sasaran utamanya adalah kelompok dan masyarakat. Sedangkan pelayanan kedokteran merupakan pelayanan kesehatan dengan tujuan utama untuk menyembuhkan penyakit dan memulihkan kesehatan, serta sasarannya tertuju untuk perseorangan dan keluarga (Buchbinder, Shanks, 2014:12)

Pada dasarnya tujuan pemberian pelayanan medik adalah memberi bantuan atau pertolongan kepada individu untuk meningkatkan kemampuannya menolong dirinya sendiri dalam menghadapi masalah kesehatannya. Untuk itulah diperlukan adanya persetujuan dari individu yang ditolong, sehingga tercipta hubungan hukum yang didasarkan kerjasama yang baik, kejujuran serta sikap saling percaya (Komalawati, 2002:84)

\section{B.3. Rumah Sakit}

Konsep rumah sakit telah bermula sejak zaman Arab kuno dulu, juga pada rumah sakit dalam sejarah Islam, rumah sakit Budha di India, dan semacam rumah sakit di Israel di mana dokter yang ada juga bertindak sebagai pendeta dan pemahaman kekuatan magis. Evolusi konsep rumah sakit modern bermula dari dasar pemikiran keimanan, kemanusiaan, dan sosial. Di tahun 325 dimulai upaya membangun rumah sakit yang berlokasi di samping berbagai katedral yang ada di dunia. Era renaissance di akhir tahun 1200-an juga berperan dalam perkembangan rumah sakit di dunia, khususnya di Eropa, ditambah lagi kemudian dengan terjadinya urbanisasi, perdagangan, dan revolusi industri yang semuanya membuat rumah sakit makin banyak dibutuhkan dan dibangun. Di tahun 1929 dilakukanlah kongres rumah sakit internasional yang pertama. The International Hospital Federation (IHF) yang berdiri tahun 1947 dengan sekretariat di London, kini punya anggota 
sekitar 90 negara di dunia.

Istilah hospital konon berakar dari kata Latin hostel yang biasa digunakan di abad pertengahan sebagai tempat bagi para pengungsi yang sakit, menderita, dan miskin. Pendapat lain oleh Willan (1990) mengatakan bahwa kata hospital berasal dari bahasa Latin hospitium, yang artinya suatu tempa/ruangan untuk menerima tamu. Sementara itu, Yu (1997) menyatakan bahwa istilah hospital berasal dari bahasa Perancis kuno dan medieval English, yang dalam kamus Inggris Oxford didefinisikan sebagai:

1. Tempat untuk istirahat dan hiburan

2. Institusi sosial untuk mereka yang membutuhkan akomodasi, lemah dan sakit.

3. Institusi sosial untuk pendidikan dan kaum muda.

4. Institusi untuk merawat mereka yang sakit dan cedera.

Definisi yang paling klasik hanya menyatakan bahwa rumah sakit adalah institusi atau fasilitas yang menyediakan pelayanan pasien rawat inap, ditambah dengan beberapa penjelasan lain. American Hospital Association di tahun 1978 menyatakan bahwa rumah sakit adalah suatu institusi yang fungsi utamanya adalah memberikan pelayanan kepada pasiendiagnostik dan terapeutik-untuk berbagai penyakit dan masalah kesehatan, baik yang bersifat bedah maupun nonbedah.

Sedangkan dalam bahasa Indonesia sendiri istilah rumah sakit mungkin berasal dari bahasa Belanda zieken huis, kendati menurut bahasa Belanda sendiri kerap juga digunakan istilah hospital (Tjandra, 2003:9). Menurut American Hospital
Association rumah sakit adalah suatu organisasi yang melalui tenaga medis profesional yang teroganisir serta sarana kedokteran, asuhan keperawatan yang berkesinabungan, diagnosis serta pengobatan penyaki yang diderita oleh pasien. Sedangkan Wolper dan Pena, menyatakan bahwa Rumah Sakit adalah tempat di mana pendidikan klinik untuk mahasiswa kedokteran, perawat dan berbagai tenaga profesi kesehatan. Berdasarkan Association of Hospital Care, rumah sakit adalah pusat di mana pelayanan kesehatan masyarakat, pendidikan serta penelitian kedokteran diselenggarakan (Anwar, 1994: 88).

Berdasarkan uraian di atas dapat disimpulkan bahwa Rumah sakit itu bukan hanya sebuah tempat, tetapi juga sebuah fasilitas, sebuah institusi, dan sebuah organisasi. Rumah sakit harus dibangun, dilengkapi dan dipelihara dengan baik untuk menjamin kesehatan dan keselamatan pasiennya serta harus menyediakan fasilitas yang lapang, tidak berdesak-desakan dan terjamin sanistasinya bagi kesembuhan pasien

Tugas dan fungsi rumah sakit adalah menyelenggarakan pelayanan kesehatan perorangan secara paripurna yang mediakan pelayanan rawat inap, rawat jalan dan gawat darurat. Pelayanan kesehatan yang diselenggarakan meliputi pelayanan kesehatan yang bersifat promotif, preventif, kuratif dan rehabilitatif.

Berdasarkan jenis pelayanan yang diberikan, rumah sakit dikategorikan dalam Rumah Sakit Umum dan Rumah Sakit Khusus. Rumah Sakit Umum memberikan pelayanan kesehatan pada semua bidang dan jenis penyakit, sedangkan Rumah Sakit Khusus memberikan pelayanan utama pada satu bidang atau satu jenis penyakit tertentu berdasarkan disiplin ilmu, golongan umur, organ, jenis penyakit, atau kekhususan lainnya (Sri, 2013:89). 
Berdasarkan pengelolaannya Rumah Sakit dapat dibagi menjadi Rumah Sakit publik dan Rumah Sakit privat. Rumah Sakit publik dapat dikelola oleh pemerintah, pemerintah daerah, dan badan hukum yang bersifat nirlaba yang dikenal dengan nama Badan Layanan Umum atau Badan Layanan Umum Daerah yang tidak dapat dialihkan menjadi rumah sakit privat.Sedangkan rumah sakit privat sebagaimana dimaksud dikelola oleh badan hukum dengan tujuan profit yang berbentuk Perseroan Terbatas atau Persero.

Berdasarkan fungsi rujukan rumah sakit umum dapat diklasifikasi sebagai berikut kelas A, B, C dan D (Sri, 2013:89). Rumah Sakit kelas A adalah rumah sakit yang mampu memberikan pelayanan kedokteran spesialis dan subspesialis luas. Oleh Pemerintah, Rumah Sakit kelas A telah ditetapkan sebagai tempat pelayanan rujukan tertinggi (top referral hospital) atau disebut pula sebagai Rumah Sakit Pusat. Rumah Sakit kelas B adalah rumah sakit yang mampu memberikan pelayanan kedokteran spesialis luas dan subspesialis terbatas. Rumah Sakit kelas B menampung pelayanan rujukan dari Rumah Sakit kabupatenRumah Sakit Kelas C adalah rumah sakit yang mampu memberikan pelayanan kedokteran spesialis terbatas seperti pelayanan bedah, spesialis anak, kebidanan dan penyakit dalam. Rumah Sakit kelas C biasanya menampung pasien yang dirujuk dari puskesmas.Sedangkan Rumah Sakit kelas D adalah rumah sakit yang bersifat transisi karena pada satu saat akan ditingkatkan menjadi Rumah Sakit kelas C.Rumah Sakit Kelas D menyediakan pelayanan kedokteran umum dan kedokteran gigi. Sama halnya dengan Rumah Sakit kelas C, Rumah Sakit kelas D juga menerima pasien rujukan dari puskesmas.

\section{B.4. Tenaga Kesehatan}

Dalam Undang-Undang

Kesehatan No. 36 Tahun 2009 disebutkan bahwa tenaga kesehatan merupakan sumber daya kesehatan yang paling utama. Sebab dengan tenanga kesehatan ini semua sumber daya kesehatan yang lain seperti fasilitas pelayanan kesehatan, perbekalan kesehatan serta teknologi dan produk teknologi dapat dikelola secara sinergis dalam rangka mencapai tujuan pembangunan kesehatan yang diharapkan. Secara hukum tenaga kesehatan di Indonesia telah diatur tersendiri sejak 22 Juli 1963 dengan keluarnya Undang-Undang No. 6 Tahun 1963 yang menggunakan acuan hukum Undang-Undang Kesehatan Tahun 1960 (CST, 1991:36).

Petugas kesehatan adalah petugas kesehatan yang professional. Petugas kesehatan yang professional mendasarkan semua perilaku dan tindakannya dalam melayani masyarakat atau pasien harus didasarkan pada standar profesi. Oleh sebab itu, setiap jenis tenaga kesehatan yang melayani di berbagai sarana atau fasilitas kesehatan harus mempunyai acuan bertindak (etika) profesi.

Pada prinsipnya perencanaan, pengadaan, pendayagunaam pembinaan, dan pengawasan mutu tenaga kesehatan ditujukan kepada seluruh tenaga kesehatan dalam menyelenggarakan upaya kesehtan. Pengadaaan dan peningkatan mutu tenaga kesehatan diselenggarakan oleh pemerintah, pemerintah daerah dan/atau masyarakat melalui pendidikan dan/atau pelatihan. Pemerintah mengatur penempatan tenaga kesehatan untuk pemerataan pelayanan kesehatan.

Tenaga kesehatan berhak mendapatkan imbalan dan perlindungan hukum dalam melaksanakan tugas sesuai 
dengan profesinya Tenaga kesehatan dalam melaksanakan tugasnya berkewajiban mengembangkan dan meningkatkan pengetahuan dan keterampilan yang dimiliki.

Dalam hal tenaga kesehatan diduga melakukan kelalaian dalam menjalankan profesinya, kelalaian tersebut harus diselesaikan terlebih dahulu melalui mediasi. Mediasi merupakan penyelesaian kasus melalui jalur nonlitigasi atau tidak melalui jalur hukum. (Sri, 2003:52)

\section{B.5. Pasien}

. Dalam perspektif etika dan hukum kesehatan kedua belah pihak, baik masyarakat atau pasien dan petugas kesehatan mempunyai hak dan kewajiban, yang saling diakui dan dihormati. Hak-hak masyarakat atau pasien harus dihargai oleh setiap petugas kesehatan, dan sebaliknya hakhak petugas kesehatan juga harus diakui dan dihargai oleh masyarakat sebagai pengguna pelayanan. Demikian juga, petugas kesehatan mempunyai kewajiban yang harus dilaksanakan untuk pasien atau masyarakat, tetapi masyarakat atau pasien harus menjalankan kewajibannya untuk petugas kesehatan yang melayaninya. (Soekidjo, 2010:172).

\section{B.6. Profil Rumah Sakit Umum} Daerah dr.Adjidarmo.

Rumah Sakit Umum Daerah Kabupaten Lebak didirikan pada tanggal 2 Mei 1952. Diprakarsai oleh dr. Adjidarmo. Pada saat didirikan, tenaga dokter yang ada adalah dr. Adjidarmo dan dr. Hank (seorang dokter dari Jerman). Pada tahun 1984 Rumah Sakit Umum Daerah Kabupaten Lebak yang sebelumnya merupakan Rumah Sakit kelas D, ditingkatkan menjadi Rumah Sakit kelas C.
Berdasarkan Peraturan Daerah Nomor 2 IPD-DPRD/1984 dan Surat Keputusan Gubernur Kepala Daerah TK I Jawa Barat Nomor 118342/SK1132.HNK/84 tanggal 20 Juni 1984. Sejak didirikan RSUD Kabupaten Lebak telah mengalami beberapa kali pergantian pimpinan yaitu : dr. Adjidarmo Tahun 1952 - 1958 2. dr. Soewarto Tahun 1958 - 1961 3. dr. Lim Teng Jin Tahun 1961 - 1962 4. dr. Soeranto Tahun 1962 - 1971 5. dr. H. Karsadi Tahun 1971 - 1981 6. dr. H. Haikin Rachmat Tahun 1981 - 19837. dr. H. Karsadi, SKM Tahun 1983 - 1985 8. dr. Hj. Rosma Yeni S. Anwar Tahun 1983 - 1994 9. dr. Hj. Farida Salim Tahun 1994 - 1999 10. dr. H. Noor Sardono, M.Kes. Tahun 1999 - 200411. drg. Indra Lukmana Tahun 2004 Sampai Sekarang Melalui Peraturan Daerah Kabupaten Lebak Nomor 29 Tahun 1996, maka ditetapkan dokter Adjidarmo sebagai nama Rumah Sakit Umum Daerah Kabupaten Lebak.

Berdasarkan Keputusan Menteri Kesehatan Republik Indonesia Nomor 651/Menkes/SK/VII/2008 tanggal $16 \mathrm{Juli}$ 2008 tentang Penetapan Kelas Rumah Sakit Umum Daerah dr. Adjidarmo Milik Pemerintah Kabupaten Lebak Provinsi Banten, maka RSUD dr.Adjidarmo mendapatkan peningkatan kelas Rumah Sakit dari Kelas C menjadi Kelas B yang ditindaklanjuti dengan Peraturan Daerah Nomor 10 Tahun 2008 Tentang Pembentukan, Organisasi, Dan Tata Kerja RSUD dr.Adjidarmo.

Rumah Sakit Umum Daerah dr.Adjidarmo, memiliki rencana Visi dan Misi pada tahun 2014-2019, yaitu :

1. Visi RSUD dr. Adjidarmo : "Menjadi Rumah Sakit yang Handal dan Berdaya Saing di Provinsi Banten"

2. Misi RSUD dr. Adjidarmo : 
a. Mewujudkan

pengelolaan keuangan rumah sakit menjadi

Badan Layanan Umum

Daerah (BLUD)

b. Mewujudkan

Peningkatan Kompetensi

Sumber Daya Manusia

Rumah Sakit

c. Mewujudkan

Peningkatan Sarana dan

Prasarana Rumah Sakit

Secara Bertahap

d. Mewujudkan

Akses Pelayanan yang Berkualitas Kepada Masyarakat

e. Mewujudkan

Akreditasi Rumah Sakit yang Berstandar Nasional

Pada sisi Manajerial, RSUD dr Adjidarmo di pimpin dan dijalankan oleh:

a. KaSubbag Umum dan Kepegawaian :Maesaroh, BA

b. KaSubbag Perlengkapan dan Rumah Tangga :Nono Tiarsono.

c. KaSubbag Hubungan Masyarakat : Budi Kuswandi, $\mathrm{SH}$.

d. KaSubbag Penyusunan Program \& SIMRS :Erwin Yudaswara, S.Si.

e. KaSubbag Pengendalian, Evaluasi, dan Laporan :Hj. Yana Dahliana, SKM.

f. KaSubbag Diklat, Litbang, dan Pemasaran :H.Agus Rifki Hidayat, S.Sos, M.Si.

g. KaSubbag

Perbendaharaan $: \mathrm{Hj} . \quad$ Nieta Setiawaty. h. KaSubbag Mobilisasi Dana :Aan Haryati.

i. KaSubbag Verifikasi dan Akuntansi :Novi Rofiah,S.Sos.

j. Kasi Pelayanan Tindakan Medik :Dr. Karleanne Lony Primasari,

k. Kasi Pembinaan Mutu Pelayanan Rujukan dan Audit Klinik :Ns. Lia Lestari,

1. Kasi Mutu Pelayanan dan Asuhan Keperawatan : $\mathrm{Hj}$. Suhestiasih, S. Kep.

m. Kasi Pembinaan SDM dan Etika Profesi Keperawatan :Mutmainah, AMd.Keb

n. Kasi Pembinaan SDM dan Pelayanan Penunjang Medik :Delina Girsang, SKM

o. Kasi Sarana dan Prasarana Medik Keperawatan dan Penunjang Medik :Hj. Edahwati, S. Kep.

Dasar Hukum pembentukan RSUD dr Adjidarmo adalah:

1. Undang-Undang Nomor 23 Tahun 2000 Tentang Pembentukan Provinsi Banten (Lembaran Negara Republik Indonesia Tahun 2000 Nomor 182 Tambahan Lembaran Negara Republik Indonesia Nomor 4010);

2. Undang-Undang Nomor 29 Tahun 2004 Tentang Praktek Kedokteran (Lembaran Negara Republik Indonesia Tahun 2004 Nomor 116 Tambahan Lembaran Negara Republik Indonesia Nomor 4431);

3. Undang-Undang Nomor 12 Tahun 2008 Tentang Perubahan Kedua atas Undang-undang Nomor 32 Tahun 2004 tentang Pemerintahan Daerah (Lembaran Negara Republik Indonesia Tahun 2008 Nomor 59 
Tambahan Lembaran Negara Republik Indonesia Nomor 4844);

4. Undang - Undang No. 25 Tahun 2009 Tentang Pelayan Publik;

5. Undang-Undang Nomor 28 Tahun 2009 Tentang Pajak Daerah dan Retribusi Daerah (Lembaran Negara Republik Indonesia Tahun 2009 Nomor 130 Tambahan Lembaran Negara Republik Indonesia Nomor 5049);

6. Undang-Undang Nomor 36 Tahun 2009 Tentang Kesehatan (Lembaga Negara Republik Indonesia Tahun 2009 Nomor 144, Tambahan Lembaga Negara Republik Indonesia Nomor 5063);

7. Undang-Undang Nomor 44 Tahun 2009 tentang Rumah Sakit (Lembaga Negara Republik Indonesia Tahun 2009 Nomor 153, Tambahan Negara Republik Indonesia Nomor 5072);

8. Peraturan Pemerintah Nomor 32 Tahun 1996 Tentang Tenaga Kesehatan (Lembaran Negara Republik Indonesia Th 1996 Nomor 49);

9. Keputusan Presiden Nomor 40 Tahun 2001 tentang Pedoman Kelembagaan dan Pengelolaan Rumah Sakit Daerah;

10. Instruksi Presiden Nomor 7 Tahun1999 tentang Akuntabilitas Kinerja Instansi Pemerintah;

11. Peraturan Menteri Kesehatan RI No. 1171 Tahun 2011 Tentang Sistem Informasi Rumah Sakit;

12. Keputusan Menteri Negara Pendayagunaan Aparatur Negara Nomor 81 Tahun 1993 Tentang Pedoman Tata Laksana Pelayanan Umum;

13. Keputusan Menteri Kesehatan Republik Indonesia Nomor 651/Menkes/SK/VII/2008 Tentang Penetapan Kelas Rumah Sakit Umum

DOI: https://doi.org/10.29313/aktualita.v2i1.4679
Daerah Dr. Adjidarmo (Lembaran

Daerah Kabupaten Lebak Provinsi Banten);

14. Instruksi Menteri

Kesehatan Republik Indonesia Nomor 826/Menkes/VII/1999 tentang pelaksanaan Pelayanan Prima Bidang Kesehatan;

15. Peraturan Daerah Kabupaten Lebak Nomor 10 Tahun 2008 Tentang Pembentukan, Organisasi, dan Tata Kerja Rumah Sakit Umum Daerah Dr. Adjidarmo (Lembaran Daerah Kab. Lebak Tahun 2008 Nomor 10);

16. Peraturan Daerah Kabupaten Lebak Nomor 7 Tahun 2009 Tentang Tata Layanan Kesehatan pada Rumah Sakit Umum Daerah Dr. Adjidarmo Kabupaten Lebak (Lembaran Daerah Kabupaten Lebak Tahun 2009 Nomor 7).

\section{Peraturan Daerah}

Kabupaten Lebak Nomor 7 Tahun 2010 Tentang Retribusi Jasa Umum pada Rumah Sakit Umum Daerah Dr. Adjidarmo Kabupaten Lebak (Lembaran Daerah Kabupaten Lebak Tahun 2010 Nomor 7)

7. Hasil Penelitian dan Pembahasan

7.1 Pertanggungjawaban Hukum BPJS Ditinjau Dari Unsur Kualitas Pelayanan Kesehatan Pasien Peserta Jaminan Kesehatan Masyarakat Menurut Undang-Undang No. 24 Tahun 2011 Tentang Badan Pelayanan Jaminan Sosial (BPJS).

Kelemahan Hukum Jaminan Sosial Nasional yaitu, lebih mengedepankan kebijakan non penal. Bahwa kebijakan non penal yang terdefinisikan dengan dalam pasal 37 UU BPJS, mengatur tentang bentuk pertanggungjawaban Good Coorporate Goverments (manajemen) dalam bentuk laporan pengelolaan program dan laporan keuangan tahunan yang telah diaudit oleh 
akuntan public kepada Presiden dengan tembusan kepada DJSN dengan waktu yang telah ditetapkan.

Istilah pengertian Pertanggungjawaban diatas mengacu pada pertanggungjawaban dalam arti yuridis, dimana pertanggungjawaban seseorang dapat dituntut, diperkarakan, dan dipersalahkan dan menerima beban sebagai akibat sendiri atau akibat perbuatan orang lain, dan menimbulkan kerugian pada orang lain atau tidak optimalnya kinerja seperti yang dilakukan oleh BPJS dengan sistem kredensialing melibatkan pihak Rumah Sakit dalam keturutsertaanya dalam pengelolaan pelayanan kesehatan.

Pihak Rumah Sakit dalam perjanjian tidak diperbolehkan untuk berperan serta dalam program Pengelolaan Pelayanan Kesehatan, namun atas dasar beberapa kebijakan dirut Rumah sakit dan BPJS, adanya kebijakan yang dibuat oleh Rumah Sakit dan BPJS melemahkan Undang-undang No 40 Tahun 2014 Tentang Persauransian.

Makna pertanggungjawaban BPJS, mengingatkan akan adanya suatu pertanggungjawaban secara hukum yang sangat berbeda, yaitu pertanggungjawaban hukum adalah pertanggungjawaban umum yang timbul karena hukum (Peraturan Perundangundangan) dan pertanggungjawaban hukum dimana seseorang bebas dari segala bentuk pertanggungjawaban karena tidak diatur oleh hukum.

Sedangkan dalam kontrak kredensialing yang dibuat Rumah Sakit dan BPJS mengerucut pada pemenuhan pertanggungjawaban manajerial para pihak, hal ini dapat dilihat dari adanya unsur manajerial yaitu:

1. Jenis pelayanan yang dapat diberikan oleh
Faskes dan waktu pelayanan;

2. Jenis pelayanan disini sebaiknya cukup rinci dan jelas baik bagi BPJS maupun Faskes

3. Jenis pelayanan yang tidak ditanggung

4. Jenis pelayanan yang tidak tertera dalam Peraturan Menteri yang berlaku, dapat disetarakan dengan tindakan yang tertera dalam peraturan dimaksud

5. Besaran Tarif pelayanan kesehatan

6. Besaran iur biaya (jika ada)

7. Mekanisme pemberian pelayanan kepada peserta

8. Mekanisme pembayaran pelayanan :

9. Proses jaga mutu dan optimalisasi kinerja Faskes

10. Tanggungjawab finansial para pihak

11. Sistim Administrasi dan Informasi

12. Kesanggupan Faskes untuk mempertahankan sertifikat mutu yang sudah diperoleh Faskes

13. Hak dan kewajiban

14. Lampiran penjelasan tentang jenis pelayanan (paket)

15. Kertas kerja negosiasi tarif

16. Kewenangan melihat medical record apabila diperlukan konfirmasi

Pendapat Dewan Pertimbangan Medik dapat digunakan sebagai pertimbangan dalam penyelesaian masalah medis 
Muniroh Hanafiah, Dey Ravena, Chepi A. Firman, Pertanggungjawaban Hukum Badan Penyelenggara...

$\begin{array}{lr}\text { Menurut Spiro } & \begin{array}{r}\text { menjelaskan } \\ \text { timbulnya }\end{array} \\ \text { Prasyarat } & \text { sebagai }\end{array}$ akuntabilitas, sebab dan kewajiban. Sebab timbulnya pertanggungjawaban diatas kemudian Spiro membagi dua arah pertanggungjawaban yaitu explicit accountability yang merujuk pada pertanggungjawaban keluar yang memberikan laporan atas tindakan yang dilakukannya dan implicit accountability cenderung pada kekurangan pengetahuan atas akibat yang dilakukan kepada yang lain atas tindakan atau keputusan yang dibuat.

\section{Explicit cause responsibility} menentukan beberapa kriteria yang berbeda dari suatu pertanggungjawaban sebagai sebab diantaranya, Resources, Knowledge, Choice and Purpose, Resources berhubungan dengan daya kapabilitas seorang untuk bertanggungjawab sebagai suatu sebab timbulnya keadaan yang harus dipertanggungjawabkan, Knowledge terkait dengan pengetahuan seorang terkait suatu keputusan yang dibuatnya, Choice terkait keputusan terkait dengan resiko yang minim sebagai sebab timbulnya pertanggungjawaban.Salah satu dasar pertimbangan pertanggungjawaban sebagai suatu sebab yang bersifat explisit berhubungan dengan purpose (maksud atau niat] dari suatu keputusan yang diambil. Spiro, dalam bukunya Responsibility on Government 1969) mendefinisikan Responsibility sebagai:

1. Accountability

(perhitungan laporan pelaksanaan tugas) yang disampaikan pada atasan atau pemberi tugas (misalnya mandatory) dari peneria tugas sebagai bawahan (misalkan mandataris), dalam batas kekuasaan yang diterimanya

2. As cause, cause adalah faktor penggerak bagi seorang pejabat dalam mengambil keputusan atau tindakan berdasarkan kehendak bebas

3. Obligation (Kewajiban), Tanggungjawab pemerintah dihubungkan dengan kedudukannyasebagai warga negara (citizen's political responsibility) dan sebagai pelaku pemerintahan.dalam hubungan ini ada empat aspek obligation, yaitu :

a. Nobles oblige, yaitu moral obligation of the rich or highborn to display honorable or charitable of conduct, unkapan ini dikenakan pada pemerintah dengan mengganti nilai rich dan highborn dengan power dan rank (position), dengan demikian pemerintah wajib menjungjung kehormatan dan nama baik seutuhnya dalam masyarakat.

b. Wajib membedakan nama jabatan dan nama pribadi dan tidak boleh mencampur adukan keduanya.seorang pejabat publik seharusnya tidak memegang kedudukan privat (misalnya perusahaan, olah raga, yayasan).

c. Wajib memegang segala resiko sebagai pejabat pemerintahan

d. Wajib menepati janji sebagai pejabat publik antara dirinya dengan pihak terkait.

Pertanggungjawaban

BPJS didasarkan pada suatu kehendak bebas dan pilihan bebas dengan adanya sutu perjanjian yang dibuat atas suatu jabatan yang melekat pada organ / badan tata kelola BPJS, jika pertanggungjawaban BPJS dihubungkan dengan fungsi organisasi dan sistem hukum maka pertanggungjawaban BPJS bersumber dari penggunaan wewenang yang diterima dari sumbernya, tindakan atas 
prakarsa sendiri Freies Ermessen dan tindakan pribadi (oknum).

$\begin{array}{ccr}\text { Bentuk } & \text { dan } & \text { aspek } \\ \text { pertanggungjawaban } & \text { BPJS } & \text { terkait }\end{array}$ dengan batas pertanggungjawaban dan evaluasi pelaksanaan tugasnya, dalam ilmu hukum dikenal dua hal yang dijadikan sasaran peratanggungjawaban, yaitu Rechtmatigheid dan Doelmatigheid, yang pertama berhubungan dengan pertanyaan sampai mana pelaksanaan tugas sesuai dengan aturan atau prosedur yang telah ditetapkan dan masih berlaku dan yang kedua berhubungan dengan sasaran pelaksanaan tugas tercapai (efektif).

$$
\text { Proses pertanggungjawaban }
$$

BPJS dimulai saat BPJS melakukan sesuatu, jika niat itu diwujudkan output, maka pertanggungjawaban berlangsung selama pasien menggunakan produk pelayanan medis, maka, proses pertanggungjawaban dilakukan menurut asas-asas terbuka, trasnparan dan

\begin{tabular}{|c|l|l|c|c|}
\hline & $1-$ & $25,00-$ & & \\
1 & 2,5996 & 64,99 & $\mathrm{D}$ & TIDAK BAIK \\
\hline \multirow{3}{*}{2} & $2,60-$ & $65,0-$ & & KURANG \\
& 3,064 & 76,6 & $\mathrm{C}$ & BAIK \\
\hline
\end{tabular}

timbal balik; langsung, langsung pada consumer/pasien secara pribadi tanpa perwakilan; Informatif dan tuntas, seperti diketahui didorong oleh manajemen pemasaran yang sehat.

Foci kebijakan pemerintahan pada ruang tanggungjawab sebagai accountability, Obligation dan cause (sebab-akibat) teori kausalitas kebijakan publik yaitu perundang-undangan yang berlaku, memperhatikan prinsip reinventing goverment, good goverment, demokratis (menyertakan stake holder dalam pembangunan baik dalam proses pelaksanaannya dan proses pengawasannya).

Pengukuran dan evaluasi pelayanan kesehatan BPJS merupakan alat manajemen dalam meningkatkan kualitas pengambilan keputusan dan akuntabilitas, untuk dapat mengetahui hal tersebut, lebih dahulu ditentukan tujuan program pelayanan kesehatan secara jelas, termasuk indikator kinerja/ukuran keberhasilan pelaksanaan program, sehingga dapat diukur tingkat kualitas pelayanan kesehatannya. pengukuran kualitas pelayanan kesehatan merupakan jembatan antara perencanaan strategis dengan laporan akuntabilitas (aplikasi teori kausalitas). BPJS akan berhasil jika terdapat bukti dan indikator ukuran pencapaian mengarah pencapaian misi. Untuk mengatakan pelaksanaan program pelayanan kesehatan berhasil atau tidak dapat diukur melalui kinerja kegiatan merupakan tingkat pencapaian target (rencana tingkat capaian) dari masing-masing indikator indikator pelayanan kesehatan minimum menurut permenkes ataupun ISO pelayanan kesehatan yang sesuai dengan rekredensialing dan tingkat pencapaian standar kredensial BPJS pada pengguna. Hasil penelitian sampel pada rumah sakit umum daerah dr Adjidarmo ditemukan kualitas pelayanan kesehatan:

Nilai kualitas pelayanan RSUD dr Adjidarmo periode sampai dengan Juni 2018 memperoleeh Nilai Tidak Baik dan Kurang baik diperlukan suatu audit oleh akuntan public mengenai kinerja, akuntabilitas kredensial BPJS pada RSUD Adjidarmo dan pengelolaan program antara BPJS dan RSUD Adjidarmo, hasil sample audit akuntan public tersebut wajib disampaikan kepada Presiden dengan tembusan kepada DJSN paling lambat per tanggal 30 Juni tahun.

Hasil tindak lanjut audit akuntan public akan ditindak lanjuti oleh BPK dengan indikator: 
1. Pemeriksaan atas Hasil Inventarisasi Aset dan Liabilitas, Pengelolaan Data Peserta dan Biaya-biaya Umum tahun buku 2013 terkait pengalihan PT Askes (Persero) menjadi BPJS Kesehatan, ditemukan 13 temuan, dan tidak sesuai rekomendasi sejulah 3 perkara

2. Pemeriksaan Kinerja atas Penyelenggaraan Program Jaminan Kesehatan Nasional (JKN) pada BPJS Kesehatan TA 2014 s.d Desember I TA 2015, dengan jumlah temuan 11, dan tidak sesuai rekomendasi sejumlah 12

3. Pemeriksaan Kinerja atas Penyelenggaraan Program Jaminan Kesehatan Nasional (JKN) pada BPJS Kesehatan TA 2015 s.d Semester I Tahun 2016, dengan jumjlah temuan 15 dan tidak sesuai rekomendasi sejumlah 26 perkara

7.2 Bentuk Pertanggungjawaban Hukum BPJS Ditinjau Dari Unsur Kualitas Pelayanan Kesehatan

Pasal 37 ayat (1) UU BPJS menentukan BPJS wajib menyampaikan pertanggungjawaban atas pelaksanaan tugasnya dalam bentuk laporan pengelolaan program dan laporan keuangan yang telah diaudit oleh akuntan publik kepada Presiden dengan tembusan kepada DJSN paling lambat tanggal 30 Juni tahun berikutnya. Kemudian pada ayat (2) menyatakan Periode laporan pengelolaan program dan laporan keuangan tahunan sebagaimana dimaksud pada ayat (1) dimulai dari 1 Januari sampai dengan 31 Desember.

Ketentuan tersebut diatas menyisakan tiga pertanyaan mendasar mengenai isi dan bentuk laporan hasil pemeriksaan BPJS? Dan legalitas pemeriksaan akuntan publik pada laporan pengelolaan program dan laporan keuangan, atau hanya laporan keuangan saja, dan laporan pertanggungjawaban BPJS perlu mendapat persetujuan direksi setelah mendapat persetujuan pengawas. Laporan pertanggungjawaban yang disampaikan kepada Presiden dengan tembusan kepada DJSN tersebut secara yuridis benar-benar sah atas nama BPJS sebagai badan hukum publik. UU BPJS tidak memberikan jawaban yang jelas mengenai persoalan ini. Pasal 37 ayat (6) UU BPJS menyatakan bentuk dan isi publikasi sebagaimana dimaksud pada ayat (5) ditetapkan oleh Direksi setelah mendapat persetujuan dari Dewan Pengawas.

Penetapan Direksi setelah mendapat persetujuan Dewan Pengawas adalah bentuk dan isi publikasi laporan pengelolaan program dan laporan keuangan yang disajikan dalam bentuk ringkasan eksekutif. Pasal 37 ayat (6) tidak merujuk pada ayat (1) yang bekenaan dengan laporan pertanggungjawaban tahunan. Tetapi Pasal 37 ayat (5) merujuk ke ayat (1).

Laporan pertanggungjawaban tahunan disahkan oleh Direksi Menurut Pasal 13 huruf k UU BPJS, Direksi diberi tugas melaporkan pelaksanaan setiap program, termasuk kondoisi keuangan, secara berkala 6(enam)bulan sekali kepada Presiden dengan tembusan kepada DJSN".

Dewan Pengawas sendiri berdasarkan Pasal 22 ayat (2) huruf d bertugas antara lain untuk menyampaikan laporan pengawasan penyelenggaraan Jaminan Sosial sebagai bagian dari laporan BPJS kepada Presiden dengan tembusan kepada DJSN

Penafsiran sistimatis penulis merumuskan bahwa pertanggungjawaban BPJS yang disampaikan kepada Presiden dengan tembusan kepada DJSN tidak logis jika ditetapkan oleh Direksi dengan 
persetujuan Dewan Pengawas (Pasal 20 UU BPJS). Laporan pertanggungjawaban pelaksanaan tugas BPJS dan publikasi ringkasan eksekutifnya merupakan wujud dari akuntabilitas publik BPJS sebagai badan hukum publik. Akuntabilitas publik merupakan landasan bagi proses penyelenggaraan jaminan sosial yang transparan dan terbuka kepada publik yang dilayani. Tujuannya adalah untuk mencegah penyalahgunaan kewenangan dan menjamin bahwa tugas dan kewenangan yang diberikan kepada BPJS diarahkan untuk memberikan manfaat yang sebesar-besarnya bagi kepentingan Peserta.

Akuntan publik yang diberi wewenang oleh undang-undang mencakup laporan pengelolaan program dan laporan keuangan, atau hanya laporan keuangan saja. bahwa untuk memastikan keabsahan laporan pertanggungjawaban BPJS Pasal 37 ayat (1) UU BPJS mengatur klausula yang dihubungkan dengan konjungsi "dan" untuk menyatakan hubungan penjumlahan yang berkaitan dengan pertanggungjawaban yang wajib disampaikan oleh BPJS kepada Presiden. Klausula tersebut adalah "laporan pengelolaan program" dan "laporan keuangan tahunan yang telah diaudit oleh akuntan publik".

Aplikasinya adalah BPJS wajib menyampaikan pertanggungjawaban atas pelaksanaan tugasnya dalam bentuk laporan pengelolaan program; dan laporan keuangan tahunan yang telah diaudit oleh akuntan publik.

Standar professional dan etika audit pemeriksaan pelaksanaan tugas BPJS sebagai badan hukum publik yang diberi kepercayaan untuk menyelenggarakan sistem jaminan sosial nasional berdasarkan 9 prinsip jaminan sosial. Sehubungan dengan itu, sebagai konsekuensi dari kewajiban BPJS menyampaikan

laporan pertanggungjawaban kepada Presiden, maka Presiden secara implicit diberikan kewenangan untuk menilai laporan pertanggungjawaban pelaksanaan tugas BPJS tersebut. Presiden dapat memberikan penilaian apakah kinerja BPJS telah sesuai dengan rencana kerja dan rencana anggaran, dan kebijakan umum yang telah ditetapkan serta telah memenuhi harapan publik dalam rangka pemenuhan hak setiap orang atas jaminan sosial. Kepastian hukum untuk menjawab ketiga pertanyaan diatas sangat diperlukan oleh BPJS. Peraturan pelaksanaan UU BPJS yang akan ditetapkan dalam waktu dekat ini hendaknya dapat memberi jawaban yuridis untuk dijadikan pedoman oleh BPJS dalam peneyelenggaraan program jaminan sosial.

Penerapan kualitas pelayanan medis terhadap hak pasien peserta BPJS berfokus pada:

1. Askes pelayanan dan kontinuitas (APK) menyelaraskan kebutuhan asuhan pasien dengan pelayanan yang sudah tersedia di rumah sakit, mengoordinasikan pelayanan, kemudian merencanakan pemulangan dan tindakan selanjutnya.

2. Hak Pasien Dan Keluarga (HPK) diantaranya diatur mengenai Etika Medis menyebutkan bahwa kriteria prinsip yang digunakan dalam mengambil keputusan tindakan apa yang terbaik bagi pasien perlu mempertimbangkan salah satunya adalah aspek agama. Hal ini sesuai dengan KODEKI melalui penjelasan pasal 4 yang menjelaskan bahwa sesungguhnya yang menyembuhkan suatu penyakit 
adalah Tuhan Yang Maha Esa sehingga seorang dokter tidak boleh merasa sombong, takabur bahkan memuji dirinya sendiri karena ilmu yang dimilikinya merupakan sebuah karunia, kemurahan dan ridhoNya

3. Asesmen Pasien asesmen Proses asesmen pasien adalah proses yang terus menerus dan dinamis yang digunakan pada sebagian besar unit kerja rawat inap dan rawat jalan. Asuhan pasien di rumah sakit diberikan dan dilaksanakan berdasarkan konsep Pelayanan berfokus pada pasien (Patient / Person Centered Care).Pola ini dipayungi oleh konsep WHO: Conceptual framework integrated peoplecentred health services. (WHO global strategy on integrated people-centred health services 2016-2026, July 2015).

4. Pelayanan Pasien Asuhan tersebut dapat berupa upaya pencegahan, paliatif, kuratif, atau rehabilitative termasuk anestesia, tindakan bedah, pengobatan, terapi suportif, atau kombinasinya, yang berdasar atas asesmen dan asesmen ulang pasien. Area asuhan risiko tinggi (termasuk resusitasi, transfusi, transplantasi organ/jaringan) dan asuhan untuk risiko tinggi atau kebutuhan populasi khusus yang membutuhkan perhatian tambahan

5. Pelayanan Anestesi dan bedah Anestesi dan sedasi umumnya merupakan suatu rangkaian proses yang dimulai dari sedasi minimal hingga anastesi penuh. Oleh karena respons pasien dapat berubahubah sepanjang berlangsungnya rangkaian tersebut maka penggunaan anestesi dansedasi diatur secara terpadu

Standar pelayanan yang berfokus pada pasien yang seharusnya dapat diterapkan pada perkara malpraktik, adapun penyebab meninggalnya malpraktik pada pasien BPJS tersebut adalah kesalahan dalam diagnose kondisi darurat, pihak rumah sakit meminta uang muka perawatan 50 persen, tidak ada ketegasan mengenai aturan sanksi untuk rumah sakit dan adanya penyimpangan administratif yang dilakukan rumah sakit.

Munculnya akibat hukum dari kelalaian dari Penyedia Layanan kesehatan Rumah Sakit dan Dokter yang menangani, wajib mempertanggungjawabkan secara hukum, karena kelalaian ini merupakan suatu perbuatan melawan hukum, oleh karena itu hukum menentukan, menurut doktrin, bahwa subjek hukum dapat mempertanggungjawabkan atas perbuatan yang akibatnya diatur oleh hukum. menurut Hans Kelsen bahwa kedudukan penyedia jasa layanan kesehatan sebagai badan hukum.

Adanya organisasi Ikatan Dokter Indonesia (IDI) sebagai wakil dari negara yang menaungi penyelenggara layanan kesehatan, dipersonifikasikan sebagai badan hukum pribadi / perorangan, bahwa IDI dan atau pihak RS telah dipertimbangkan sebagai badan hukum, berbeda dengan pribadi natura, yaitu manusia sepenuhnya sebagai subjek pendukung hak dan kewajiban, menurut Kelsen tanggungjawab hukum dan kewajiban hukum ditujukan pada badan hukum tetapi kewajiban itu berada diatas pundak individu-individu sebagai organ yang berkompeten harus memenuhi kewajiban badan hukum, perbuatan mereka membentuk isi dari kewajiban ini. 
Hak pasien dalam jika di analogikan sebagai konsumen, maka secara garis besar dapat dibagi dalam tiga hak yang menjadi prinsip dasar, yaitu untuk mencegah konsumen dari kerugian, baik kerugian personal, maupun kerugian harta kekayaan; untuk memperoleh barang dan/atau jasa dengan harga yang wajar; dan untuk memperoleh penyelesaian yang patut terhadap permasalahan yang dihadapi.

Diatur pula mengenai Pencegahan terjadinya kelalaian etik Dokter, yaitu :

1. Mengidentifikasi Pasien dengan benar

2. Meningkatkan komunikasi yang efektif

3. Meningkatkan keamanan obat yang harus diwaspadai.

4. Memastikan Lokasi Pembedahan Yang benar

5. Mengurangi Resiko Infeksi

6. Mengurangi Resiko Paien terjatuh.

Dari ketiga prinsip tersebut, jelaslah prinsip terakhir merupakan masalah dasar dalam proses penyelesaian sengketa konsumen, dimana konsumen selalu mendapatkan kesulitan dalam proses penyelesaian sengketa terhadap permasalahan yang patut dihadapi. Apabila hak-hak konsumen benar-benar akan dilindungi, maka hak-hak konsumen yang disebutkan diatas haruslah terpenuhi, baik oleh pemerintah maupun oleh pelaku usaha.

Pihak RS sebagai pelaku usaha jasa layanan kesehatan tidak dapat lagi sewenang-wenang dengan kekuasaannya yang ada sebagai penyedia barang dan/atau jasa memuat ketentuanketentuan dalam proses pejanjian yang hanya menguntungkan pihaknya sebagai pelaku usaha saja, namun juga harus memperdulikan hak-hak konsumen. Kedua pihak dalam transaksi tersebut, yaitu konsumen dan pelaku usaha merupakan pihak-pihak yang harus mendapat perlindungan secara hukum oleh pihak negara.

Permasalahan pelayanan pada Fasilitas kesehatan tingkat pertama yang dilakukan oleh Puskesmas atau yang setara, biasanya pasien memanipulasi surat rujukan agar dapat dirujuk ke Rumah Sakit Fasilitas kesehatan tingkat kedua, manipulasi surat rujukan tersebut akan menimbulkan suatu permasalahan, karena perbedaan diagnose, perbedaan diagnose Faskes pertama dan Faskes kedua akan berbeda dari segi kemampuan dokter yang memeriksa dan alat yang digunakan, yang menjadi permasalahan adalah ketika karakter kondisional kegawatdaruratan yang ditangani Faskes Pertama kemudian dibuatkan manipulasi surat rujukan ke faskes kedua. Permasalahannya adalah apabila diagnosanya diganti, maka keakuratan diagnosa dokter akan dipertanyakan, sehingga potensi malpraktek dokter akan terbuka lebar, dan tentunya hal ini juga akan melanggar kode etik dokter.

Penerapan pelayanan kesehatan dalam undang-Undang No. 36 Tentang Kesehatan dan Undang -Undang Juncto No. 24 Tahun 2011 Tentang BPJS, yaitu adanya kepastian hukum. Kepastian hukum adalah suatu kondisi yang tidak mudah untuk berubah-ubah sesuai dengan perubahan dalam masyarakat dan dapat ditaati oleh masyarakat pada waktu dan tempat manapun. Sehingga dengan tidak mudahnya hukum untuk berubahubah, maka setiap tindakan yang dilakukan oleh masyarakat bisa ditentukan apakah perbuatan tersebut melanggar dan menyimpang dari peraturan hukum atau tidak. Dengan demikian maka Pemerintah dapat 
menjamin agar Peserta BPJS Kesehatan mendapatkan pelayanan kesehatan yang dibutuhkan sesuai dengan standar yang telah ditetapkan oleh pemerintah dan BPJS Kesehatan.

Dalam upaya meningkatkan pelayanan kesehatan yang diselenggarakan kepada pesertanya, BPJS Kesehtan melakukan proses kredensialing sebelum bekerja sama dengan Fasilitas Kesehatan. Kredensialing ini merupakan proses evaluasi oleh BPJS Kesehatan terhadap Fasilitas Kesehatan yang bersangkutan untuk menentukan apakah Fasilitas Kesehatan tersebut layak diberi kewenangan untuk menjadi Fasilitas Kesehatan yang menyelenggarakan pelayanan kesehatan kepada Peserta BPJS Kesehatan untuk suatu periode tertentu. Tujuan dari proses kredensialing ini adalahuntuk mengetahui kapasitas dan kualitas fasilitas kesehatan yang akan bekerjasama dengan BPJS sehingga peserta dapat dilayani dan tujuan pembangunan kesehatan dapat tercapai.

\section{PENUTUP}

1. Kesimpulan

Berdasarkan pembahasan dalam penelitian ini, peneliti dapat menyimpulkan beberapa hasil penelitian sebagai berikut:

1. Bentuk dan aspek pertanggungjawaban Hukum BPJS digunakan teori Rechtmatigheid dan Doelmatigheid , unsur perbutaan melawan hukum BPJS bisa ditentukan oleh pengukuran dan evaluasi kualitas pelayanan kesehatan BPJS dengan menggunakan indikator perjanjian kredensialing dan unsure kerugian yang diderita Rumah sakit dan pasien, kerugian yang diderita rumah sakit dapat berupa buruknya pengelolaan program yang diterapkan BPJS pada rumah sakit, sedangkan kerugian pasien dapat berupa kerugian materil atau imateril atas buruknya kualitas pelayanan rumah sakit. Jadi dalam satu peristiwa hukum terdapat dua perjanjian, hubungan hukumnya yaitu antara BPJS, rumah sakit dan pasien, namun banyak regulasi yang mengarahkan penyelesaian sengketa pada segi pertanggungjawaban GCG BPJS dan rumah sakit, hal ini disimpulkan penulis tidak melindungi hak pasien dan keluarga jika terjadi kerugian yang diderita pasien.

2. Bentuk Pertanggungjawaban hukum BPJS ditinjau dari unsur kualitas pelayanan Kesehatan Pasien peserta Jaminan Kesehatan Masyarakat berdasarkan Undang-Undang No. 24 Tahun 2011 Tentang Badan Pelayanan Jaminan Sosial (BPJS), bahwa kedudukan penyedia jasa layanan kesehatan sebagai badan hukum, melekat doktrin doktrin kausalitas (sebabakibat) sebagai bentuk dari azas equality before the law

\section{Saran}

Saran penulis terhadap permasalan kualitas pelayanan BPJS terhadap pasien peserta BPJS adalah sebagai berikut:

1. Audit laporan pengelolaan program dan audit akuntabilitas yang dilakukan oleh akuntan publik, dan badan pengawas keuangan tidak dapat menjadi tolak ukur BPJS melakukan 
Muniroh Hanafiah, Dey Ravena, Chepi A. Firman, Pertanggungjawaban Hukum Badan Penyelenggara...

perbuatan melawan hukum, meskipun adanya unsur kerugian yang diderita oleh rumah sakit dari buruknya pengelolaan program BPJS terutama dalam segi anggaran, disarankan pengelolaan program dan pengelolaan program BPJS dapat dibenahi agar Rumah sakit dan Pasien dapat menggunakan produk jaminan social BPJS lebih baik dan dapat disetarakan dengan kualitas asuransi swasta, dan tentunya hal ini dapat mengurangi sengketa hukum.

2. Pasien BPJS menyangkut pada hajat hidup orang banyak, Disarankan penerapan standar kualitas pelayanan kesehatan BPJS agar memberikan benefit asuransi dalam bentuk perlindungan dan kepastian hukum pada pasien terkait adanya kelalaian yang mungkin dilakukan oleh petugas kesehatan, serta memberikan pelayanan baik sebagai public governments dalam bentuk kemudahan-kemudahan klaim asuransi, ganti rugi dan lainlainnya, penerapan kebijakan penyelesaian sengketa medis dilakukan agar dibukanya akses aspek hukum terhadap tindakan kelalaian doketer pada pasien sebagai bentuk penerapan kualitas pelayanan BPJS dan rumah sakit.

\section{Daftar Pustaka}

Anny Isfandyarie, 2006, Tanggung Jawab Hukum Dan Sanski Bagi Dokter Buku 1, Prestasi Pustaka Publisher, Malang.

Arifin Soeria Atmadja, 1986, Mekanisme Pertanggungjawaban
Keuangan Negara Suatu Tinjauan Yuridis, Gramedia Pustaka, Jakarta.

Azrul Azwar, 1996, Menjaga Mutu Pelayanan Kesehatan, Pustaka Sinar Harapan, Jakarta.

Bambang Wibowo,Sutoto, 2018, Komisi Akreditasi Rumah Sakit Standar Nasional Akreditasi Rumah Sakit Jilid pertama, Kementrian Kesehatan Republik Indonesia, Jakarta .

Buchbinder B. Sharon, Shanks Nancy, 2014, Buku Ajar Manajemen Pelayanan Kesehatan, Penerbit Buku Kedokteran EGC, Jakarta

CST Kansil, 1991, Pengantar Hukum Kesehatan Indonesia, Rineka Cipta, Jakarta.

E.Utrecht, Saleh Djindang, 1985, Pengantar Hukum Administrai Negara, PT.Ichtiar Baru, Jakarta.

Firdaus, 2007, Pertanggungjawaban Presiden Dalam Negara Hukum Demokrasi, Yrama Widya, Bandung.

Hans kelsen, 2009, General Theory of Law And State, The Lawbook Exchange Ltd., New Jersey.

Head W J, 1997, Pengantar Umum Hukum Ekonomi, Proyek Elips, Jakarta.

Hendry Campble Black, 1979, Black's Law dictionary, Fifth Edition, ST.Paul.Minn West Publishing Co, USA.

M.C Kechnie, 1983, Webster New Universal Unabriged Dictionary, Second Edition,Simon Schuester, USA.

Mochtar Kusumaatmadja, 2000, Pengantar Ilmu hukum: Suatu Pengenalan Pertama Ruang Lingkup 
Muniroh Hanafiah, Dey Ravena, Chepi A. Firman, Pertanggungjawaban Hukum Badan Penyelenggara...

Berlakunya Ilmu Hukum, Buku I, Alumni, Bandung.

Putri E. Asih, 2014, Paham Jaminan Kesehatan Nasional Seri Buku 4, Friedrich-Ebert-Stiftung, Jakarta.

Robert D.Lee Jr, Ronald W.Johnson, 1978, Public Budgeting System, University Park Press, Baltimore.

Soekidjo Notoatmodjo, 2010, Etika Dan Hukum Kesehatan, Penerbit Rineka Cipta, Jakarta.

Sri Siswati, 2013, Etika Dan Hukum Kesehatan Dalam Perspektif UndangUndang Kesehatan, Rajawali, Padang.

Suryandono Widodo, 2005, Jaminan Sosial, Fakultas Hukum Universitas Indonesia, Jakarta.

Sutarto, 2003, Encyclopedia Administration, MCMLXXVII, Jakarta.

Taliziduhu Ndraha, 2003, Kybernology I, Rineka Cipta, Jakarta.

Tjandra Aditama Y, 2003, Manajemen Administrasi Rumah Sakit, Jakarta.

Veronica Komalawati, 2002, Peranan Inform Consent dalam Transaksi Terapeutik (Persetujuan Dalam Hubungan Dokter dan Pasien) Suatu Tinjauan Yuridis, Citra Aditya Bakti, Bandung. 
Muniroh Hanafiah, Dey Ravena, Chepi A. Firman, Pertanggungjawaban Hukum Badan Penyelenggara... 